\title{
FDA Approvable Letter
}

National Cancer Institute

\section{Source}

National Cancer Institute. FDA Approvable Letter. NCI Thesaurus. Code C142551.

A letter from the Food and Drug Administration to a study sponsor that lists issues to be resolved before an approval can be issued. 